\title{
The origin of eclogite xenoliths entrained in the Jericho kimberlite, Nunavut
}

\author{
K.A. Smart ${ }^{1}$, L.M. Heaman ${ }^{1}$, T. Chacko ${ }^{1}$, A. Simonetti ${ }^{1}$, M. Kopylova ${ }^{2}$, D. Mah ${ }^{3}$, and D. \\ Daniels ${ }^{4}$ \\ ${ }^{I}$ Department of Earth and Atmospheric Sciences, University of Alberta, Canada \\ ${ }^{2}$ Department of Earth and Ocean Sciences, University of British Columbia, Canada \\ ${ }^{3}$ Olivut Resources Ltd \\ ${ }^{4}$ Tahera Diamond Corporation
}

\begin{abstract}
Introduction
Eclogite xenoliths occur in many kimberlite pipes and although they are often a subordinate mantle xenolith lithology, eclogites can provide important information on the composition and evolution of cratonic lithospheric mantle. Numerous studies on mantle eclogites have resulted in two dominant hypotheses proposed for their origin: 1) remnants of subducted and metamorphosed oceanic crust (e.g. Helmstaedt and Doig, 1975; Jacob et al., 1994) or 2) cumulates of basaltic magmas at high pressure (e.g. O'Hara and Yoder, 1967; Smyth et al., 1989). The former hypothesis is widely accepted in the literature (e.g. Jacob, 2004), although the latter is still advocated by some authors (e.g. Griffin et al., 2007). Interestingly, although the proportion of eclogite within the cratonic lithospheric mantle is small $(<5 \%$, Schulze, 1989), the proportion of E-type diamonds and eclogitic mineral inclusions in diamond is surprisingly large. Although eclogitic diamonds are abundant in some deposits, diamond-bearing eclogites are relatively rare, limiting our understanding of the origin of E-type diamonds and their host rocks. In this study we report the mineral major- and trace-element contents and in-situ $\mathrm{Sr}$ and $\mathrm{Pb}$ isotope compositions of clinopyroxene for nineteen Jericho eclogites, including a spectacular suite of diamond-bearing eclogite xenoliths recently recovered from the Jericho kimberlite.
\end{abstract}

\section{Background}

The 173 Ma Jericho kimberlite (Heaman et al., 2006) is located in the northern Slave craton in Nunavut, Canada approximately $150 \mathrm{~km}$ north of the Lac de Gras kimberlite field and contains a high proportion of eclogite in its entrained mantle material. There have been a number of previous studies on Jericho eclogites (Cookenboo et al., 1999; Kopylova et al., 1999; Heaman et al., 2002, 2006; Schmidberger et al., 2005), which have focused on geothermometry, major element mineral chemistry and geochronology. The majority of Jericho eclogites are bi-minerallic garnet and clinopyroxene, but can contain diamond, kyanite, corundum, rutile, phlogopite, apatite and zircon. The Jericho eclogites can be subdivided into three broad groups based on garnet composition; 1) Fe-rich (up to 26.5 wt \% FeO), includes zircon-bearing xenoliths, 2) Ca-rich (up to 17.5 wt.\% $\mathrm{CaO}$ ), includes kyanite- bearing eclogites, and 3) Mg-rich (up to 21 wt.\% $\mathrm{MgO}$ ), includes all recovered diamond-bearing eclogites. The diamondiferous eclogites are dominantly garnet-clinopyroxene rocks, but diamond of can make up to $20 \%$ of the mode. De Stefano et al. (this volume) have identified a large range of $\mathrm{C}$ isotopes in the Jericho E-type diamonds that range to extremely light isotopic values $\left(\delta^{13} \mathrm{C}=-5\right.$ to $-39 \%$ ) .

Temperatures calculated for the Jericho eclogites, using the calibration of Ellis and Green (1979), range from $920-1180^{\circ} \mathrm{C}$ at $50 \mathrm{kbar}$, and fit well with temperatures previously reported by Kopylova et al. (1999) and Heaman et al. (2006). Four diamond-bearing eclogites in this study have a restricted temperature range from $1000-1015^{\circ} \mathrm{C}$ at $50 \mathrm{kbar}$, a characteristic noted by Cookenboo et al. (1998). Temperatures at Jericho define a unimodal distribution, in contrast to the bimodal distribution observed in Diavik eclogite xenoliths (Schmidberger et al., 2007). Zircon-bearing eclogites from Jericho record Paleoproterozoic ages ca. 1.7-2.0 Ga, and Hf model ages of 2.1-2.3 Ga and are proposed to represent pieces of oceanic crust that underwent east-directed subduction beneath the Slave craton prior to the ca. 1.9-1.85 Ga Wopmay orogen (Heaman et al., 2002, 2006; Schmidberger et al., 2005). Mesoproterozoic zircon $\mathrm{U}-\mathrm{Pb}$ and whole-rock eclogite $\mathrm{Nd}$ model ages have also been reported at Jericho, indicating a later perturbation and metasomatic overprint (Heaman et al., 2006).

Results: Trace element composition of clinopyroxene and garnet

The trace-element compositions of garnet and clinopyroxene in mineral separates and thin sections were determined using laser ablation quadrupole ICPMS. All samples were examined carefully for alteration and inclusions, and for thin sections, all measurements were taken away from grain boundaries or any areas of secondary alteration. Chondrite-normalized plots (Fig. 1) show the distinct LREE- and HREE-enriched nature of clinopyroxene and garnet, respectively, in the diamond-bearing eclogites when compared to the Ferich eclogites. Clinopyroxene from diamondiferous eclogites are markedly enriched in LREE such as $\mathrm{Ce}_{\mathrm{N}}$ (91-130), $\mathrm{La}_{\mathrm{N}}(78-103)$ and $\mathrm{Nd}_{\mathrm{N}}$ (77-90) compared to the Fe- and Ca-rich suites $(0.2-23,0.16-18$, and 0.7236 , respectively). Additionally, garnets from the 
diamond eclogites are enriched in HREE and have strongly fractionated $\mathrm{HREE}_{\mathrm{N}} \quad\left(\mathrm{Lu}_{\mathrm{N}} \sim 31-53\right.$ and $[\mathrm{Gd} / \mathrm{Lu}]_{\mathrm{N}} \sim 0.17$ ), compared to the non-diamondiferous suite $\left(\mathrm{Lu}_{\mathrm{N}} \sim 4-30,[\mathrm{Gd} / \mathrm{Lu}]_{\mathrm{N}} \sim 1-3\right)$. Both garnet and clinopyroxene from $\mathrm{Fe}$-rich eclogites also display positive $\mathrm{Eu}$ anomalies that are absent in the diamondiferous eclogites.
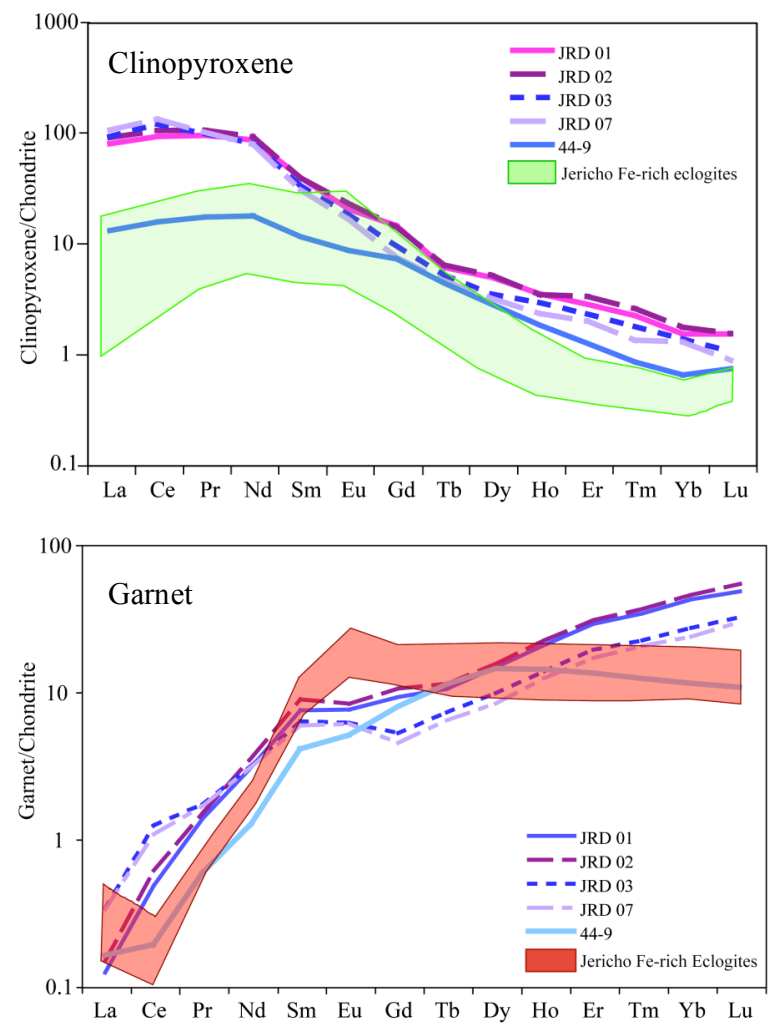

Figure 1. Chondrite normalized REE plots of clinopyroxene (top) and garnet (bottom). Diamond eclogites are JRD-01 through -07, 44-9 is a high-Mg, non-diamondiferous eclogite.

Normalizing values from McDonough and Sun (1995).

$\mathrm{Sr}$ and $\mathrm{Pb}$ isotope composition of clinopyroxene $\mathrm{Sr}$ and $\mathrm{Pb}$ isotopes were measured in clinopyroxene mineral separates and thin sections by LA-MC-ICPMS. ${ }^{87} \mathrm{Sr} /{ }^{86} \mathrm{Sr}$ results from non-diamondiferous eclogites range from 0.7036 to 0.7044 , clustering at 0.7040 . These eclogites have a large spread in ${ }^{206} \mathrm{~Pb} /{ }^{204} \mathrm{~Pb}$ values, from $14.70-18.00$ and a complementary range in ${ }^{207} \mathrm{~Pb} /{ }^{204} \mathrm{~Pb}$ from $14.90-15.37$. Tightly clustered $\mathrm{Pb}$ isotope data from one eclogite xenolith yields a 2.2 Ga Stacey-Kramers model age, whereas other xenoliths hint at Neoarchean to Paleoproterozoic model ages. In contrast, diamondbearing eclogites have more homogeneous and more radiogenic isotopic compositions. ${ }^{87} \mathrm{Sr} /{ }^{86} \mathrm{Sr}$ values of clinopyroxene from these rocks cluster at 0.7057 ; which exceeds than the value reported for all other Jericho eclogites and the Jericho kimberlite itself (0.7052, Heaman et al., 2006). $\mathrm{Pb}$ isotopic compositions $\left({ }^{206} \mathrm{~Pb} /{ }^{204} \mathrm{~Pb}=18.6 ;{ }^{207} \mathrm{~Pb} /{ }^{204} \mathrm{~Pb}=15.5\right)$ plot below the Stacey-Kramers curve and to the right of the Geochron on a $\mathrm{Pb}-\mathrm{Pb}$ plot. Age estimations for the diamond-bearing eclogites are not possible from the current data.

\section{Discussion}

Our study clearly indicates that the Mg-rich, diamondbearing eclogites are distinct in terms of their trace element compositions, suggesting this group has a very different origin. Jericho Fe- and Ca-rich eclogites share features with other suites of eclogite xenoliths interpreted to have a oceanic-crust protolith (Jacob, 2004), including largely basaltic compositions, positive $\mathrm{Eu}$ and $\mathrm{Sr}$ anomalies, flat or depleted reconstructed $\mathrm{HREE}_{\mathrm{N}}$ and elevated garnet and clinopyroxene $\delta^{18} \mathrm{O}$ of $6-7 \%$, similar to the conclusions of Heaman et al. (2002; 2006) and Schmidberger et al. (2007).

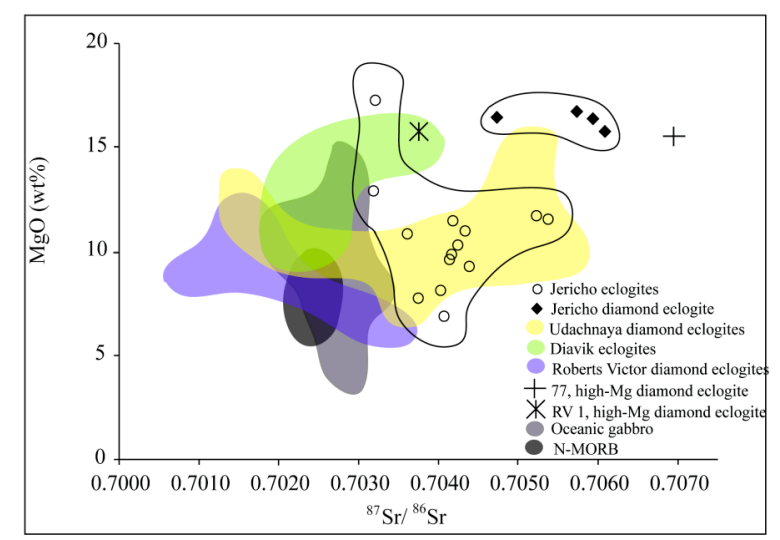

Figure 2. $\mathrm{Sr}$ isotopes and $\mathrm{MgO}$ contents in clinopyroxene for the Jericho eclogites and diamond-bearing eclogite suites from Roberts Victor (Jacob et al., 2005), Udachnaya (Jacob et al., 1994; Jacob and Foley, 1999) and Diavik

(Schmidberger et al., 2007). Oceanic gabbro field from Bach et al. (2001).

Origin of high-Mg, diamondiferous eclogites

The origin of the high- $\mathrm{MgO}$, diamond-rich eclogites at Jericho is enigmatic. The $\mathrm{Sr}$ isotope compositions of clinopyroxene (average of 0.7057 ), is not consistent with derivation from oceanic crust or as a cumulate of a basalt magma derived from partial melting of peridotite. If the diamond eclogites at Jericho formed as pieces of subducted oceanic crust at $\sim 2.0 \mathrm{Ga}$, contemporaneous with the age of previously reported zircon-bearing eclogites, then the ${ }^{87} \mathrm{Sr} /{ }^{86} \mathrm{Sr}$ would be approximately 0.7013 , or trend towards 0.704 if the oceanic crust interacted with 2.0 Ga seawater (e.g. Schmidberger et al., 2007). The chondrite-normalized trace element compositions of garnet and clinopyroxne (Fig.1) are also not reconcilable with an oceanic crust origin. The extreme LREE enrichment in clinopyroxene, coupled with depletion in HFSE and presence of phlogopite in these xenoliths, is probably due to carbonatite metasomatism and perhaps may be related to the carbonatite metasomatism at Jericho described by Heaman et al. (2006). The fractionated and enriched HREE patterns observed in whole-rock reconstructed diamondiferous eclogites are not compatible with low-pressure plagioclase accumulation (e.g. Jacob, 2004), but instead may be representative of higher-pressure garnet accumulation.

Diamondiferous eclogites with similar high-MgO contents are rare worldwide, but two examples have been reported: one at Udachnaya (77, Jacob et al., 1994) and one at Roberts Victor (RV1, Jacob et al., 2005). However both eclogites lack the extreme LREE enrichment in clinopyroxene, the fractionated HREE observed in Jericho garnet and the highly radiogenic 
${ }^{87} \mathrm{Sr} /{ }^{86} \mathrm{Sr}$ values recorded in the Jericho samples (Fig. 2). Thus there are no other comparable high- $\mathrm{Mg}$, diamond-bearing eclogites to the Jericho diamondbearing suite.

The Jericho diamond-bearing eclogites are geochemically most similar to a subset of nondiamond, high $\mathrm{MgO}$ eclogites from Koidu (Barth et al., 2002). The major elements and REE compositions of garnet and clinopyroxene from the two suites are similar. Likewise, the Koidu eclogites have fractionated HREE in garnet and enriched LREE in clinopyroxene. Fractionated HREE, high $\mathrm{Mg}$ and $\mathrm{Cr}$ content coupled with mantle-like O isotopes led Barth et al. (2002) to propose a cumulate origin from primary high pressures melts for this subset of Koidu eclogites, similar to the conclusion of Cookenboo et al. (1998) for the Jericho diamond eclogites. If this is correct, then simple modeling should produce the observed trace element patterns obtained in this study. However, model cumulates formed by $15 \%$ batch melts from various mantle lithologies fail to reproduce the trace element patterns observed in the Jericho diamondbearing eclogites. A single-stage high-pressure cumulate origin for the Jericho high-Mg eclogites is thus unlikely. We envisage a different and unique origin for the Jericho diamond-bearing eclogite involving: 1) partial melting and melt extraction from a normal eclogite (with basalt-like geochemistry), in a mixed peridotite and eclogite assemblage (e.g. Yaxley and Green, 1998) 2) melt-facilitated Fe-Mg equilibration of residual eclogite minerals with peridotite to produce the high-Mg mineral composition, and 3) carbonatite metasomatism that increases both the LREE contents and ${ }^{87} \mathrm{Sr} /{ }^{86} \mathrm{Sr}$ of the eclogites and facilitates diamond formation.

\section{References}

Barth, M.G., Rudnick, R.L., Horn, I., McDonough, W.F., Spicuzza, M.J.. Valley, J.W., Haggerty, S.E., 2002. Geochemistry of xenolithic eclogites from West Africa. Part 2: Origins of high $\mathrm{MgO}$ eclogites. Geochimica et Cosmochimica Acta, 66 (24): 43254434.

Bach, W., Alt, J.C., Niu, Y., Humphris, S.E., Erzinger, J., Dick, H.J.B., 2001. The geochemical consequences of late-stage low-grade alteration of lower ocean crust at the SW Indian Ridge: Results form ODP Hole 735B (Leg 176). Geochimica et Cosmochimica Acta, 65 (19): 3267-3287.

Cookenboo, H.O., Kopylova, M.G., Daoud, D.K., 1998. A chemically and texturally distinct layer of diamondiferous eclogite beneath the Slave craton, Northern Canada. Extended Abstracts, $7^{\text {th }}$ International Kimberlite Conference, Cape Town, 164-166.

De Stefano, A., Kopylova, M.G., Cartigny, P., Afanasiev, V., 2008. Diamonds and eclogites of the Jericho kimberlite (Northern Canada). Extended Abstract , 9 International Kimberlite Conference (this volume).

Ellis, D.J., Green, D.H., 1979. An experimental study of the effect of $\mathrm{Ca}$ upon garnet-clinopyroxene $\mathrm{Fe}-\mathrm{Mg}$ exchange equilibria. Contributions to Mineralogy and Petrology, 71, 13-33.
Griffin, W.L., O'Reilly, S.Y. 2007.Cratonic lithospheric mantle:Is anything subducted?Episodes, 30: 43-53.

Heaman, L.M., Creaser, R.A., Cookenboo, H.O., 2002. Extreme enrichment of HFSE in Jericho eclogite xenoliths: A crypic record of Paleoproterozoic subduction, partial melting, and metasomatism beneath the Slave Craton, Canada. Geology, 30 (6): 507-510.

Heaman, L.M., Creaser, R.A., Cookenboo, H.O., Chacko, T. 2006. Multi-stage modification of the Northern slave mantle lithosphere: evidence from ziron-and diamond-bearing eclogite xenoliths entrained in Jericho kimberlite, Canada. Journal of Petrololgy, 47: 821-858

Helmstaedt, H., Doig, R., 1975. Eclogite nodules from kimberlite pipes in the Colorado Plateau-samples of subducted Franciscan type oceanic lithosphere. Physics and Chemistry of the Earth, 9: 95-111.

Jacob, D. E. (2004). Nature and origin of eclogite xenoliths from kimberlites. Lithos, 77: 295-316.

Jacob, D.E., Jagoutz, E., Lowry, D., Mattey, D., Kudrjavtseva. G., 1994. Diamondiferous eclogites from Siberia: Remnants of Archean oceanic crust. Geochimica et Cosmochimica Acta, 58 (23): 51915207.

Jacob, D.E., Foley, S.F., 1999. Evidence for Archean ocean crust with low high field strength element signature from diamondiferous eclogite xenoliths. Lithos, 48: 317-336

Jacob, D.E., Bizimis, M., Salters, V.J.M. 2005., Lu-Hf and geochemical systematics of recycled ancient oceanic crust: evidence from Roberts Victor eclogites. Contributions to Mineralogy and Petrology, 148: 707-720.

O'Hara, M.J., Yoder, H.S., 1967. Formation and fractionation of basic magmas at high pressures, Scottish Journal of Geology, 3: 67-117.

Kopylova, M.G., Russell, J.K., Cookenboo, H., 1999. Mapping the Lithosphere beneath the North Central Slave Craton. In: Proceedings of the $7^{\text {th }}$ International Kimberlite Conference, Cape Town, 1: 468-479.

MacGregor, I.D., Manton, W.I. 1986. Roberts Victor eclogites: ancient oceanic crust. Journal of Geophysical Research, 91 (B14): 14063-14079.

Schmidberger, S.S., Heaman, L.M., Simonetti, A., Creaser, R.A., Cookenboo, H.O. 2005. Formation of Paleoproterozoic eclogitic mantle, Slave Province (Canada): Insights from in-situ $\mathrm{Hf}$ and $\mathrm{U}-\mathrm{Pb}$ isotopic analyses of mantle zircons. Earth and Planetary Science Letters 240: 621-633.

Schmidberger, S.S., Simonetti, A., Heaman, L.M., Creaser, R.A., Whiteford, S. $2007 \mathrm{Lu}-\mathrm{Hf}$, in-situ $\mathrm{Sr}$ and $\mathrm{Pb}$ isotope and trace element systematics for mantle eclogites from the Diavik diamond mine: Evidence for Paleoproterozoic subduction beneath the Slave craton, Canada. Earth and Planetary Science Letters, 254: 55-68.

Schulze, D.J., 1989. Constraints on the abundance of eclogite in the upper mantle, Journal of Geophysical Research, 94: 4205-4212.

Smyth, J.R., Caporuscio, F.A., McCormick, T. 1989. Mantle eclogites: evidence of igneous fractionation in the mantle. Earth and Planetary Science Letters 93: 133-141.

Yaxley, G.M., Green, D.H., 1998. Reactions between eclogite and peridotite: mantle refertilization by subduction of oceanic crust. Schweiz. Mineral. Petrogr. Mitt, 78, 243-255. 